Dušan

Grlja

\section{Taking the People vs. Power Bloc Antagonism Further: On Laclau's Populist Reason and European Left's Political Strategy}

\section{Bionote}

Dušan Grlja (1972) studied sociology in Belgrade and was editor-in-chief of Prelom (2006-2010), journal for images and politics. He has published essays on politics, ideology, culture and art form an Althusserian Marxist perspective.

The intensified and clearly evident crisis of the capitalist world-system during the last decade gave rise to an increased number of various anti-systemic movements and sentiments, thus setting the main task for the contemporary European Left in terms of articulating this oppositional potential into a viable emancipatory politics. Hence, the leftist political strategy - mainly the one expounded by Podemos and, to a lesser extent, by Syriza - has focused on populism in the sense that late Ernesto Laclau has given this term. The importance of Laclau's theory of populism for contemporary left movements is affirmed in the 2015 book of conversations with Chantal Mouffe (Laclau's longtime partner) by Íñigo Errejón, the Secretary for Policy and Strategy and Campaigning of Podemos. ${ }^{1}$ Unlike the English translation of its title In

$1 \quad$ Although the influence of Laclau and Mouffe's theories is not so immediate in the case of Syriza, it can still be clearly discerned in the fact that some of its leading figures studied in the University of Essex. Former finance minister Yanis Varoufakis got his PhD there, while Rena Dourou, the governor of Athens, and Foteini Vaki, a member of parliament, were Laclau's students there. the Name of the People, the Spanish original Construir pueblo (Constituting the People) undoubtedly refers to Laclau's central notion of the underlying mechanism of any kind of proper political act. Nonetheless, Laclau's conception of populism is historically and geographically specific in so far as it is based on Latin American political experiences, and especially the Argentinian ones tied to the long-standing political current of Peronism. Many commentators of Laclau's 2005 seminal book On Populist Reason disregard that it was largely written in conjunction with the rise of new leftist populist politics in Latin America such as those represented by Hugo Chávez in Venezuela, Rafael Correa in Ecuador and Néstor Kirchner and his wife Cristina Fernández in Argentina, ${ }^{2}$ begging thus the question whether his theorizations can be immediately applied to the European historical context as well as the present state of affairs in the EU. ${ }^{3}$ Still, this is not the main problem in weighing practical political applicability of Laclau's theory. So, I would like to offer here an account of some practical contributions, as well as limitations, of Laclau's political theory, in

2 Laclau was seen as the key influence on Kirchner as he consulted him on crucial matters of political strategy.

3 The political experiences of Venezuela and Bolivia are very present in Podemos' strategy since its most prominent figures like Pablo Iglesias, Íñigo Errejón and Juan Carlos Mondero worked as political advisors in those countries. Errejón speaks of "Latin-Americanization" in the EU, "a situation of progressive divorce between representatives and represented, collapse in the capacity of existing institutional models to meet citizens' demands, and increasing middleclass impoverishment." Íñigo Errejón and Chantal Mouffe, Podemos: In the Name of the People (London: Lawrence and Wishart, 2016), 93-4, but finds the main difference is in the type of state, as in Europe there is something to defend, "our - weak - social state, public services, and security for the working-class majority," ibid., 131, rather than having to build it from scratch like in the Latin-American countries. 
order to open the question of how the analysis of those shortcomings can be utilized for rethinking the presentday strategies of the European Left.

The general theory of society developed by Ernesto Laclau and Chantal Mouffe in Hegemony and Socialist Strategy: Towards a Radical Democratic Politics - a book published in 1985 that articulates post-Marxism as a theoretical and political position - postulates the social as the terrain of symbolical practices. Consequently, society is a discourse, since it always represents an always unstable hegemonization of the meaning of floating signifiers that is secured by suturing the discursive field with an empty one. "[T]he necessary terrain for the constitution of every social practice $[\ldots][\mathrm{w}] \mathrm{e}$ will call [...] the field of discursivity [...] [I]t determines at the same time the necessarily discursive character of any object, and the impossibility of any given discourse to implement a final suture."4 Discourse is "the primary terrain of the constitution of objectivity as such" 5 and it becomes coextensive or equivalent with the social. It also becomes coextensive with the political, since it represents the equivalent of hegemonic struggle, and, finally, hegemony follows the logic of populism. Accordingly, all social action is discursive through and through. This position, which could be termed as pandiscursive, was maybe an adequate starting point for the critique of class reductionism in classical Marxist theory and it was surely well-suited for the then trendy poststructuralism. Yet again the 2008 crisis has shown that capitalism is clearly not as much of a symbolical system but rather a very material one, one that virtually needs no discourse for its functioning. I am not claiming here that capitalist world system can operate without the support

4 Ernesto Laclau and Chantal Mouffe, Hegemony and Socialist Strategy (London and New York: Verso, 1985), 111.

5 Ernesto Laclau, On Populist Reason (London and New York: Verso, 2005), 68. of political power or ideological constructs, but just that the key of its existence lays in its specific form of material coercion. Capitalism is a system of class rule that, on the basis of commodity-monetary economy, succeeded to subjugate a vast number of people by depriving them of means of subsistence. Driven by the fact that money is needed for obtaining the basic living necessities, people have no other choice but to voluntary submit to others that are in possession of it and thus work for the benefit of those. ${ }^{6}$ The radical historical novelty of capitalism is the possibility of exploitation through wage labor without recourse to previous forms of extra-economic coercion, such as slavery, serfdom or similar relations of personal domination. ${ }^{7}$

It is not only when it comes to austerity measures and bailing out banks that the inevitable logic of economy gets summoned (the infamous neoliberal TINA argument), but the so-called invisible hand of the market represents a very real force that commands the everyday lives of billions of people all over the globe. Its logic is not necessarily discursive or, as Laclau would later theorize,

6 I intentionally deviated from the usual Marxist terminology ("means of production" and "general equivalent") in order to highlight the current situation of financial capital domination in the West that is a consequence of "classical" mass production processes being globally rearranged. The point is that the raison d'etre of capitalism is not the production of commodities as such, but the production of surplus value, regardless of commodities actually produced.

$7 \quad$ As we all very well know, those relations are far from being entirely absent; moreover, one could say that they are subsumed under capitalist relations of production. Actually, Laclau began his career as an advocate of the modes of production theory arguing that previous historical modes of production can be articulated with and subsumed under the capitalist one, as he theorized in the 1971 essay "Feudalism and Capitalism in Latin America," New Left Review, No. 67 (MayJune 1971), 19-38. 
rhetorical, ${ }^{8}$ but more of a mute, self-explanatory and quite inescapable logic of everyday material practices. Laclau and Mouffe's theory of symbolical constitution of society is unambiguous in asserting the primacy of the discursive in such an extent that they, criticizing Foucault's notion of discourse, claim that there could be no non-discursive practices. "Our analysis rejects the distinction between discursive and non-discursive practices. It affirms [...] that every object is constituted as an object of discourse, insofar as no object is given outside every discursive condition of emergence [...]"9 Thus, the main deficiency of Laclau's theory is its sole focus on the discursive or the symbolical while neglecting material determinations, or, in terms of traditional Marxist theory, losing sight of determination by the economy in the last instance. I think that, in terms of theoretical analysis, a return to the critique of political economy is necessary today, since we are witnessing, at least from the 2008 crisis on, a major shift in the structure of the capitalist system. ${ }^{10}$ In other words, due

8 His final study entitled The Rhetorical Foundations of Society was published in 2014

9 Laclau and Mouffe, Hegemony and Socialist Strategy, 107. "The main consequence of a break with the discursive/extradiscursive dichotomy is the abandonment of the thought/ reality opposition, and hence a major enlargement of the field of those categories which can account for social relations. Synonymy, metonymy, metaphor are not forms of thought that add a second sense to a primary, constitutive literality of social relations; instead, they are part of the primary terrain itself in which the social is constituted." Ibid., 110.

10 I am not advocating a complete "return" to an objective, economic analysis that would counter "subjective" or actor analyses. Although there are already numerous studies of financial capital and financialization, as well as theorizations of the subjectivity that is born out of this process - the figure of the indebted, I find that a lot of those easily ignore or are oblivious of the actual world capitalist economy configuration to deep crisis the neoliberal arrangement will have to be renegotiated, and renegotiated within a context that is more likely to be Eurasian than the Atlantic one.

Now, it may be wrong to claim that Laclau's theory of populism did not stand the test of the 2008 crisis since it actually became a frequent reference point for the leftwing anti-austerity movements galvanized in response to the crisis and the modes of its management. Thus, there must be something very productive in Laclau's theory in terms of political strategy. In my opinion, it is precisely the Manichean moment of populism: "Them or us!" Drawing upon Karl Schmitt's theorization of the enemy, Laclau's notion of populism hinges on this operation of division or, in his terms, "the formation of an internal antagonistic frontier." Laclau has, over the years, used different terms for this division: "the underdog" vs. "the establishment" or "the elites," "the little man" vs. "the institutional system," while the key part of Podemos' vocabulary is the opposition between people and the caste. But, I think that for the purposes of a political analysis of the neoliberal constellation of forces, the most adequate term would be the one that Laclau has used at the very beginning of his theorizations of populism in the 1977 essay "Towards a Theory of Populism" - the People vs. Power Bloc antagonism. ${ }^{12}$ Clearly, this corresponds to the present-day situation where the neoliberal state

and its effects on the working class (de)composition across the "Atlantic civilization," and of the centrality of financial capital.
11

12 Laclau, On Populist Reason, 74.

Ifind that the term "power bloc" is quite adequate since the ruling class is never a completely unified entity as it is comprised not only of professional politicians, but also of various businessmen that hold sway over the economy. It also allows for state apparatuses' personnel, like state administration or police officers or soldiers, to find themselves at the people's side of the divide, actually not comprising a part of the power bloc although being under its command. 
has gone rogue on its citizens, failing to be the represent of the interests of its constituents, thus progressively antagonizing people vis-à-vis the established powers. In other words, such a representation crisis opens the way for a populist rupture, i.e., "dichotomization of the local political spectrum through the emergence of an equivalential chain of unsatisfied demands... [and] the unification of these various demands into a stable system of signification." ${ }^{13}$ However, Laclau's theory remains insufficient, since this antagonism does not pertain exclusively to the formation of political identities or their discursive construction, but also to the economic as well as broader social practices that do not have to be discursively articulated in order to perpetuate the dominant class rule. His theory of populism is solely concerned with the making of political identities, ${ }^{14}$ thus reducing any kind of true political action to discursive construction of the people.

A further problem with Laclau and Mouffe's theory is its sole focus on "organic crisis" when a hegemonic project becomes unstable and unable to satisfy particular social demands which, in turn, establish a chain of equivalences through radical-democratic interpellations ${ }^{15}$ or the

13 Laclau, On Populist Reason, 74.

14 The Making of Political Identities is the title of the 1994 collection of essays edited by Laclau.

15 "The popular-democratic interpellation not only has no precise class content, but is the domain of ideological class struggle par excellence. Every class struggles at the ideological level simultaneously as class and as the people, or rather, tries to give coherence to its ideological discourse by presenting its class objectives as the consummation of popular objectives." Ernesto Laclau, Politics and Ideology in Marxist Theory (London: New Left Books, 1977), 108-9. "[C]lasses cannot assert their hegemony without articulating the people in their discourse; and the specific form of this articulation in the case of a class which seeks to confront the power bloc as a whole, in order to assert its hegemony, will be populism." Ibid., 196. rhetorical process of naming the people ${ }^{16}$ in opposition to the power bloc. Their idea of radical democracy, crucial for the contemporary European left strategy, suffers from the same exclusive attention on the moment of obvious crisis of a hegemonic project and open antagonism, thus failing to provide or steering clear of any theorizations of a new social order, other than that it would be grounded on a new system of differences and new exclusions. Hence, radical democracy becomes a perpetual process of identitarian struggle whereby one hegemonic project gets replaced by another: "Democracy is [...] about building the procedures and mechanisms which allow for a never-ending dispute over the broadest possible range of topics." ${ }^{17}$ A similar limit could be discerned in the cases of Syriza and Podemos: quite successful in mobilizing the people against the corrupted state, and eventually enjoying a substantial electoral success, but unable to significantly change political mechanisms of decision or to even challenge the dominant socioeconomic order. Also, the concept of radical democracy is born out of Laclau and Mouffe's critique of class reductionism that they see as the vehicle for breaking away from the traditional Marxist model of revolution - the "dictatorship of proletariat" - and for situating the socialist project firmly within the "democratic imaginary": "The task of the Left therefore cannot be to renounce liberal-democratic ideology, but on the contrary, to deepen and expand it in the direction of a radical and plural democracy." ${ }^{18}$ Thus, the political

16 "[O]ur approach to the question of popular identities is grounded, precisely, in the performative dimension of naming." Laclau, On Populist Reason, 103. "[T] he unity of the object is a retroactive effect of naming it." Ibid., 108.

17 Errejón, in Errejón and Mouffe, Podemos, 37.

18 Laclau and Mouffe, Hegemony and Socialist Strategy, 177. "It is necessary [...] to broaden the domain of the exercise of democratic rights beyond the limited traditional field of 
struggle is confined to the mechanisms of parliamentary democracy and aimed at electoral process that would enable the representatives of newly constructed people to wage a "war of position" within the government. ${ }^{19}$ An additional deficiency of Laclau's theory of populism is that by postulating demands as "the smallest unit of political analysis,"20 it implies a situation where any kind of political action predicates the existence of the state as the only actor capable of satisfying a demand, therefore leaving no room for autonomous politics of the people.

Now, how does all this concretely bear on a possible political strategy for the left? Populism is certainly a good mobilizing strategy, but it can be much more since it points to a fundamental social antagonism - class struggle. Laclau's theory of populism provides quite an adequate analysis of the moment of intense crisis and the evident antagonism, but it can only be the starting point

'citizenship.' As regards the extension of democratic rights from the classic 'political' domain to that of the economy, this is the terrain of the specifically anti-capitalist struggle [...] [that] defends the right of the social agent to equality and to participation as a producer and not only as a citizen.” Ibid., 185.

19 Errejón clearly states this in his afterword for the English edition: "[T]his involves imitating neoliberalism, but for the opposite ends: building new majorities so that the progressive governments of the future can institute a set of transformations and reforms such that, even when they subsequently lose power - and they all lose power eventually - their adversaries will have to govern in a very similar way to their predecessors. In other words, we need to build a new 'everydayness' that can pervade the cultural terrain, as well as public administration, the social fabric and the socio-economic model, so that limits are put on the possibilities of oligarchic regression, and we increase the potential for advancing in a popular and democratic direction.” Errejón and Mouffe, Podemos, 159.

20 Laclau, On Populist Reason, 73. for the emergence of a collective political subjectivity that has to become active ${ }^{21}$ in order to go beyond its symbolical, discursively constructed identification. Thus, I think that the productivity of the People vs. Power Bloc antagonism should not be limited just to the creation of a new, collective political identity, but should be taken further as a vehicle for establishing a new kind of social relations. In practical terms, this would mean self-organizing on egalitarian principles, bearing in mind that equality is not an ideal to strive for but the basic condition of any emancipatory political project. Both Podemos and Syriza have risen out of movements that rejected the existing representational mechanisms and practiced forms of direct democracy, like plenums or general assemblies, but the electoral successes of both organizations seem to have created a rift between those that adhere to the horizontality of movements and those that privilege the organizational form of a political party. While Errejón and Mouffe advocate their populist strategy as a "war of position within the state"22 against the "exodus strategy" promoted by

21 Both Laclau and Mouffe, as well as Errejón, give a prominent place to the notion of affect in politics. "Affective involvement as an engine of mobilization has been key to us: the recovery of the joy of being together, the solidarity between strangers - so present in our rallies and events - the belief in victory and its fearless affirmation." Errejón and Mouffe, Podemos, 61. Errejón's usage of this notion, which received a wide circulation among so many radical leftist theories, boils down to a commonsense observation that collective action engenders a collective spirit.

22 Errejón describes his Latin-American experiences in the following manner: "I lived through, worked and advised on, and was present at, the processes though which plebeian or subaltern coalitions were gaining access to the state, coalitions that had entered into a part of the state, the government, but were surrounded by conservative powers intent on limiting the scope of the changes. I thus lived through a war of position inside the state...” Errejón and Mouffe, Podemos, 83. 
Antonio Negri and Michael Hardt, it is clear that the question of state or political power is still the central one for any viable socialist strategy. Although the battle over the state apparatuses remains an important site of political struggle, without the practice of both political and economic equality "outside the state" it is largely in vain. Thus, it is necessary to keep the antagonism between people and power bloc active, since it not only traverses the within/outside the state dichotomy but, more importantly, enables to constantly rally the forces for the task of building people's self-government and self-management in the broadest sense. ${ }^{23}$

23 Now, this invites a strange notion of institutionalization of antagonism. Mouffe proposes that it could be done by sublimating antagonism into "agonism": "[A]ntagonism can manifest itself in two ways: in friend-enemy form, or as what I call 'agonism,' which takes place between 'adversaries.' The latter is a sublimated form of the antagonistic relation, in which the opponents know there is no rational solution to their conflict and that they will never be able to agree, but accept the legitimacy of the adversaries in defending their position. This requires the availability of institutions capable of channeling conflict into an agonistic, rather than antagonistic form.” Errejón and Mouffe, Podemos, 58. I think that we in the so-called Western Balkans region have a singular historical experience of socialist Yugoslavia and a way of institutionalizing antagonism that is not only completely different from Mouffe's solution within the confines of pluralist democracy, but much more radical - the incorporation of withering away of the state as the foundational principle of socio-political life. Despite the outcome in which Yugoslavia as a state completely withered away, I am convinced that the Yugoslav socialist experiment, in all its contradictory facets, offers a fertile ground for rethinking the strategy of contemporary left. 